\title{
EUROPEAN STANDARDS FOR ACCESS TO PROFESSIONAL LEGAL ASSISTANCE AND ENFORCEMENT ISSUES IN UKRAINE
}

\section{Oksana Krushnitska}

\section{INTRODUCTION}

In Part 1 of Art. 59 of the Constitution of Ukraine it is defined that everyone has the right to professional legal assistance, and in cases provided by law, this assistance is provided free of charge ${ }^{1}$. The possibility of receiving free assistance is an additional guarantee for access to justice for those who cannot afford to pay for legal services. Therefore, any free assistant programs should have grounds for providing public services.

Legal assistance is an integral part of any justice, both international and national. International legal documents do not provide specific grounds for providing free assistance but require that the decision-making procedures for providing free legal services be fair and effective.

There are fundamental differences between the member states of the Council of Europe in the paradigm, organization, and management of legal assistant systems. Regarding the paradigm of systems, the common goal in some states is to ensure universal access to legal services and justice, while in other states legal assistance can be provided only to those most in need.

Ensuring the realization of the right to free legal assistance, in accordance with the specific conditions for its providing, requires the implementation by the state of an effective legal and organizational mechanism based on European standards.

The study of professional legal assistance was given attention by such scholars as: O.A. Banchuk, O.M. Bandurka, T.V. Varfolomeyeva, M.S. Demkova, I.B. Koliushko, A.T. Komzyuk and others. The problems of organization of the Institute of free legal assistance (hereinafter - FLA) were investigated by many native scholars, in particular, Ye. Bova, R. Tytykalo, L. Tatsiy, M. Antonovych, A. Bogma, as well as foreign scholars: R. Smith, R. Cassin, M. Kiku, F. Reagan, but these studies are relevant today, as there are still many problems in this area.

The research methodology is based on a systematic scientific analysis of European standards for access to professional legal assistance and the problem of enforcement in Ukraine, in determining the effectiveness of the legal

\footnotetext{
${ }^{1}$ Constitution of Ukraine: Law of Ukraine of 06.28.1996 No. 254k/96-VR. Vidomosti of the Verkhovna Rada of Ukraine (VVR), 1996, No. 30, p. 141.
} 
regulation of this method of protection and the development of proposals of recommendations for further improvement and proper application in national legislation.

\section{Legal and regulatory framework of free legal asisstance in Ukraine}

According to the practice of the European Court of Human Rights, Art. 6 of the Convention for the Protection of Human Rights and Fundamental Freedoms, the need for legal assistance in the interests of justice should be determined based on:

- the severity of the charges and the severity of the possible punishment;

- the complexity of the legal and factual circumstances of the case;

- difficult life circumstances in which the person is ${ }^{2}$.

Most assistance programs are available to citizens of the respective country, EU citizens, as well as foreign citizens legally or illegally residing in that country.

On December 20, 2012, the United Nations General Assembly adopted the Principles and guidelines for access to legal assistance in the criminal justice system, which contains standards for the providing of free legal assistance. These principles invite states to implement and strengthen measures to provide effective legal assistance around the world.

The right to free assistance of a defender is expressly established in Article 6 of the European Convention for the Protection of Human Rights and in Article 14 of the International Covenant on Civil and Political Rights ${ }^{3}$.

The right to professional legal assistance belongs to the constitutional guarantees of human rights and freedoms and the constitutional guarantees of the administration of justice. It is no coincidence that among all kinds of legal assistance, the assistance of a lawyer is governed by the constitutional and international law, and the right to other types of legal assistance is enshrined at the level of legislation.

The right to professional legal assistance is one of the procedural guarantees that promotes the fair trial of the rights and legitimate interests of not only participants in the judiciary, but also of society and the state as a whole. The rule of law cannot exist without an independent and professional judiciary, and the latter cannot function without an organized and independent legal profession that has to deal with the case fairly and professionally. It is

\footnotetext{
${ }^{2}$ Convention for the Protection of Human Rights and Fundamental Freedoms of 04/04/1950. Convention by Law No. 475/97-VR of 07.17.97.

${ }^{3}$ International Covenant on Civil and Political Rights of 12.16.1966. The International Covenant was ratified by Decree of the Presidium of the Supreme Council of the Ukrainian SSR N 2148-VIII (2148-08) of 10.19.73.
} 
the institution of the Bar that should be a reliable support of the judicial authority and the judiciary. Such a thesis is confirmed by a number of international documents and legislation of EU countries ${ }^{4}$.

Securing the exclusive representation of another person by a lawyer in court is aimed at ensuring a high level of quality and efficiency in providing professional legal assistance and is one of the guarantees of everyone's right to a fair trial. The right to professional legal assistance is an integral part of the right to judicial protection (Article 55 of the Constitution). In its turn, the right to a fair trial is an element of the rule of law (Article 8 of the Constitution).

By establishing the exclusive right of the Bar to exercise its powers in court, the State undertakes a positive obligation to ensure the effective exercise of the right of each person to the professional legal assistance provided for in Art. 59 and 131-2 of the Constitution.

Assertion at the legislative level of the rights, duties, guarantees of advocacy, as well as the special procedure for holding to account for their violation, special procedure of access to the profession, the obligation of observance of the lawyer's secrecy and the advocate immunity are aimed at ensuring the proper implementation of the norms of the Constitution for ensuring the human rights and fundamental freedoms in the provision of professional legal assistance ${ }^{5}$.

The exclusive right of lawyers to exercise their functions of defense and representation in courts is consistent with the international practice of the leading states and promotes the formation of a legal profession with unitary standards and ethical rules. The repeal of the mentioned provisions of Art. 131-2 of the Constitution will significantly narrow the content of the human right to judicial protection and, consequently, violate the substance of the fundamental right of everyone to judicial protection and a fair trial.

The free legal assistance system (hereinafter referred to as FLA) is a relatively new state human rights institution that is gaining in popularity with the public. Today, the FLA team has numerous lawyers and attorneys across Ukraine who are actively working with citizens in need of legal assistance. Classical lawyers at one time perceived the emergence of this institution as unfavorable. They considered this fact inadmissible, because a new competitor will "cut off" their clients. However, the idea of free legal

\footnotetext{
${ }^{4}$ Forming of the free legal assistance system in Ukraine [Electronic source]. Available at: http://legalaid.gov.ua/ua/operatyvna-info/formuvannia-systemy.

${ }^{5}$ Forming of the free legal assistance system in Ukraine [Electronic source]. Available at: http://legalaid.gov.ua/ua/operatyvna-info/formuvannia-systemy.
} 
assistance, the strengthening of the system and further improvement of its work have been actively promoted in recent years ${ }^{6}$.

Recently, the category of people who are able to get free secondary legal assistance was significantly expanded. It includes combatants, internally displaced persons, children, as well as victims of family abuse or genderbased violence. The vast majority of FLA clients are low-income earners, i.e. no more than two subsistence wages.

The basic legal assistance includes the following types of legal services:

- providing legal information;

- providing legal advice and clarification;

- preparation of statements, complaints and other documents of a legal character (except documents of a procedural character);

- providing assistance in accessing a person to secondary legal assistance and mediation.

Free secondary legal assistance (hereinafter referred to as FSLA) means the creation of the equal opportunities for persons to access justice, and includes such types of legal services:

- defense against the prosecution;

- representation of interests of persons entitled to such assistance in courts, other state bodies, bodies of local self-government, before other persons;

- settling procedural documents.

In the case of providing free secondary legal assistance in civil proceedings, the costs of providing professional legal assistance are not subject to apportionment between the parties and are at state expenses. The issues of financing the legal assistance system are not governed by civil procedural law, and therefore, these state expenses are not included in legal costs in civil proceedings. The costs of litigants for professional legal assistance have substantive and procedural aspects.

In the material sense, the expenses on the professional legal assistance are the payment for legal services rendered, the amount and procedure of payment of which are determined by the terms of the legal assistance agreement. The freedom-of-contract doctrine gives the parties the opportunity to determine its terms (Article 627 of the Civil Code of Ukraine), in particular regarding the payment (part 1 of Article 632 of the Civil Code of Ukraine).

In Ukraine, there is an ambiguous situation of the participation of lawyers in the system of free legal assistance. Article 25 of the Law of Ukraine

${ }^{6}$ Issues of the decentralization process of service delivery in the united territorial communities: a collection of roundtable papers and abstracts, Kyiv, April 18, 2019 / under gen. ed. of R.V. Voitovych, P.V. Vorona. Kyiv, “ArtEk”, 2019. 217 p. 
"On Advocacy and Legal Practice" dated July 5, 2012, determines that lawyers are subjects of free legal assistance. However, the Law of Ukraine "On Free Legal Assistance" (paragraph 2 of Part 1 of Article 15) restricts the range of subjects providing secondary legal assistance free of charge only to lawyers included in the register of lawyers providing such assistance, and therefore does not take into account the person's convention right to choose a lawyer. In addition, own standards and rules for the work of lawyers in the system of free legal assistance, which compete with the Rules of Lawyers Ethics and the normative acts that regulate the lawyer's activity were created. This position of the state is contradictory since professional associations of lawyers are virtually deprived of the opportunity to influence the free legal assistance system, "public lawyers" significantly restrict the choice of lawyers for legal assistance, and lawyers outside this system cannot fulfill their important professional duty. All this leads to a decrease in the efficiency of providing legal assistance to lawyers and the loss of their independence as a self-governing professional institution.

It should be emphasized that free legal assistance is usually provided to representatives of vulnerable groups and individuals who, due to their personal circumstances, are unable to protect their own interests in the case. The European Court of Human Rights takes into account the education and social status of the applicant and evaluates them in light of the complexity of the case.

According to Article 59 of the Constitution of Ukraine, everyone has the right to professional legal assistance. In cases provided by law, this assistance is provided free of charge. Everyone is free to choose a defender of his or her rights ${ }^{7}$.

Initially, the right to free legal assistance to specific categories of citizens was established by separate legislative acts, including the law of Ukraine "On the status of war veterans, guarantees of their social protection" dated October 22, $1993^{8}$, "On refugees and persons in need of additional or temporary protection" July $8,2011^{9}$, "On the Protection of Childhood" April 26, 2001 ${ }^{10}$, and others.

However, a single act that would unify not only the subjective composition of persons entitled to professional legal assistance but also provide for mechanisms

\footnotetext{
${ }^{7}$ Constitution of Ukraine: Law of Ukraine of 06.28.1996 No. 254k/96-VR. Vidomosti of the Verkhovna Rada of Ukraine (VVR), 1996, No. 30, p. 141.

${ }^{8}$ About the status of war veterans, guarantees of their social protection: the Law of Ukraine of October 22, 1993. Vidomosti of the Verkhovna Rada of Ukraine (VVR), 1993, No. 45, p. 425.

${ }^{9}$ About the status of war veterans, guarantees of their social protection: the Law of Ukraine of October 22, 1993. Vidomosti of the Verkhovna Rada of Ukraine (VVR), 1993, No. 45, p. 425.

${ }^{10}$ On the protection of childhood: Law of Ukraine of April 26, 2001. Vidomosti of the Verkhovna Rada of Ukraine (VVR), 2001, No. 30, p. 142.
} 
for its implementation have not been adopted. Being a member of the international community, Ukraine constantly receives recommendations from leading organizations on the implementation of a free legal assistance system.

In 2005, the Parliamentary Assembly of the Council of Europe called on the Ukrainian authorities to improve access to justice by introducing a system of free legal assistance in accordance with the standards of the Council of Europe and the case-law of the European Court of Human Rights.

Already in 2011, the Parliamentary Assembly of the Council of Europe, in the context of reforming the national prosecutor's office, recommended the oversight function to replace the strengthening role of the Ombudsman and the introduction of a free legal assistance system.

The basic approach to determining the number of persons entitled to free secondary legal assistance was first identified in the Concept for the Formation of a Legal Assistance System in Ukraine, approved by Decree of the President of Ukraine on June 9, 2006 No. 509/2006. Thus, in subparagraph 3 of paragraph 2 of section III of this document, it is established that the human right to free secondary legal assistance should be determined taking into account justice and the level of material support of a person ${ }^{11}$.

The Law of Ukraine "On Free Legal Assistance" dated June 1, 2000 No. 1768-III determined the subjects of the right to free professional legal assistance $^{12}$.

In accordance with international obligations, the Law on Free Legal Assistance is in force in Ukraine, it regulates legal relations in the sphere of providing free legal assistance to the subjects of the right to free primary legal assistance and to the subjects of the right to free secondary legal assistance established by this Law. Article 1 of this law says that free legal assistance is legal assistance that is guaranteed by the state and is fully or partially provided at the expense of the State budget of Ukraine, local budgets and other sources.

All persons under the jurisdiction of Ukraine are entitled to free primary legal assistance in accordance with the Constitution of Ukraine and this Law. The subjects of the providing of free primary legal assistance in Ukraine are executive authorities, local government, individuals, legal entities of private law and specialized institutions.

The mechanism for dealing with citizens whose appeals are groundless is not established by the legislation. The employees of the center cannot refuse to accept the appeal, although they may know that there is no judicial perspective.

\footnotetext{
${ }^{11}$ On the Concept of the formation of a system of free legal assistance in Ukraine: Decree of the President of Ukraine of June 9, 2006 No. 509/2006.

${ }^{12}$ About free legal assistance: Law of Ukraine dated 02.06.2011 No. 3460-VI. Vidomosti of the Verkhovna Rada of Ukraine (VVR), 2011, No. 51, p. 577.
} 
The EU Council has also recognized early access to legal assistance by a lawyer as one of the key components of a long-term plan to strengthen and protect the rights of suspected criminal proceedings in all EU countries. When "states use the need test to determine the eligibility for legal assistance, they must provide persons, who are in urgent need of legal assistance and are in police departments, detention centers or courts, with the preliminary legal assistance until it becomes clear whether these persons are entitled to receive such assistance" ${ }^{\prime 13}$.

The problem of timely legal assistance to a detainee in Ukraine is exacerbated by the fact that in almost $23 \%$ of cases the actual detention time does not coincide with the time indicated in the detention protocol. Moreover, there is a tendency for violations of the right of access to legal assistance of a lawyer in the early stages of criminal proceedings. Thus, the number of cases where the actual detention time does not coincide with the time specified in the detention protocol has increased by $20 \%$ over the past year and the number of violations of the client's rights to a confidential meeting with a client has increased by $17 \%{ }^{14}$.

In this regard, it is necessary to direct the concerted efforts of all criminal justice entities to ensure the effective early access to a lawyer for any suspect or accused, as provided for by the legislation of Ukraine and ECtHR practice. In particular, a cardinal change in the attitude of detention authorities and investigators and prosecutors to their obligations, under which they should be interested in the presence of a lawyer in the pre-trial investigation is necessary to avoid both the recognition of the evidence obtained inadmissible in the future and possible responsibility for violation of the right of defense provided by Art. 374 of the Criminal Code of Ukraine. In addition, the introduction of a system of automatic detention in Ukraine could help to eradicate violations of a person's right to defense in the early stages of criminal proceedings.

At the same time, some provisions of the current legislation governing the right of a person to legal assistance require further improvement and alignment with international standards. Thus, according to Art. 17 of the Law, the Centers may not only appoint a lawyer providing free secondary legal assistance, but also apply for the removal of a lawyer from the register of lawyers providing free secondary legal assistance, on grounds of, inter alia, the improper fulfillment of obligations under the contract specifications.

${ }^{13}$ Legal assistance in Europe: minimum requirements under international law [Electronic source]. Available at: http://osf.to/legal-aid-standards.

${ }^{14}$ Forming of the free legal assistance system in Ukraine [Electronic source]. Available at: http://legalaid.gov.ua/ua/operatyvna-info/formuvannia-systemy. 
Some scholars are concerned that the wide range of Centers' powers, which may be established outside the Centers Regulations Act (paragraph 13 of Article 17 of the Law), makes it possible to suggest that public administration of the Bar may become unlimited. We believe that the enshrined legislative control of the state over the activities of lawyers should be recognized as the fulfillment of the obligation to ensure the implementation of the paragraph 3 of Art. 6 of the ECtHR. However, in order for such an intervention to be in line with European standards, it must meet the stated aim - to provide effective free legal assistance - while being minimal - only to the extent of the achievement of the stated aim.

A free secondary legal assistant is a type of state guarantee that creates equal opportunities for people to have access to justice. It includes legal services such as protection; representation of interests of persons entitled to free secondary legal assistance in courts, other state bodies, in local authorities against other persons; preparation of procedural documents ${ }^{15}$.

One of the drawbacks of this Law was that it provided for long stages of the entry into force of some of its provisions.

It is important that the document did not impose any restrictions on the subjects of the right to free primary legal assistance, while only a small number of persons received the right to free secondary legal assistance.

Only on January 1, 2013, the centers of free secondary legal assistance, as state institutions, began to provide free secondary professional legal assistance to persons:

- to whom administrative detention has been applied;

- to whom an administrative arrest has been applied;

- who, in accordance with the provisions of the criminal procedure law, are considered to be detained;

- in respect of who pretrial detention has been selected;

- in criminal proceedings in respect of who, in accordance with the provisions of the Criminal Procedure Code of Ukraine, a lawyer, a prosecutor, an investigating judge or a court are involved in the protection of a separate procedural action;

- sentenced to imprisonment, detention in a disciplinary battalion of servicemen or imprisonment.

Since July 2016, the number of persons entitled to free secondary legal assistance in civil and administrative cases has been significantly expanded. These include:

- persons under the jurisdiction of Ukraine, if the average monthly total income of their family is below the subsistence minimum, calculated and

${ }^{15}$ About free legal assistance: Law of Ukraine dated 02.06.2011 No. 3460-VI. Vidomosti of the Verkhovna Rada of Ukraine (VVR), 2011, No. 51, p. 577. 
approved in accordance with the Law of Ukraine "On the subsistence minimum" dated July $15,1999^{16}$ for persons belonging to the main social and demographic groups of the population;

- persons with disabilities who receive a pension or a benefit instead of a pension of less than two subsistence minimums for disabled persons;

- orphans, children deprived of parental care, who are in difficult life circumstances, or who have suffered because of military operations and armed conflicts;

- persons covered by the Law of Ukraine "On Refugees and Persons in Need of Additional or Temporary Protection" dated July 8, 2011, from the moment when the person submits the application for recognition as a refugee or the person in need of additional protection in Ukraine until the adoption of the final decision on the application, as well as foreigners and stateless persons detained in order to identify and ensure forced expulsion from the moment of detention;

- war veterans and persons covered by the Law of Ukraine "On the status of war veterans, guarantees of their social protection" dated October 22, 1993, persons with special merits and special labor merits to their homeland, as well as those who became victims of Nazi persecution, on issues related to their social protection;

- persons in respect of whom the court is considering a case of limiting the civil legal capacity of an individual, declaring him legally incompetent, and the resumption of the civil legal capacity of an individual;

- persons in respect of whom the court is considering the case of the providing of psychiatric care in a forced manner;

- persons rehabilitated in accordance with the legislation of Ukraine on issues related to rehabilitation.

It is necessary to highlight some of the achievements of these innovations:

1) the legislator did not limit the guarantee of the providing of free secondary professional legal assistance only to citizens of Ukraine, extending it to persons who are under the jurisdiction of Ukraine;

2) victims of criminal offenses can now use the right to free professional legal assistance;

3) elimination of the requirement for low financial support for children in difficult life circumstances to receive free secondary professional legal assistance.

\footnotetext{
${ }^{16}$ On the living wage: Law of Ukraine of July 15, 1999. Vidomosti of the Verkhovna Rada of Ukraine (VVR), 1999, No. 38, p. 348.
} 


\section{Problematic aspects and possible ways to improve the professional legal assistance}

However, some weaknesses in these legislative changes can be highlighted. They should be analyzed in more detail:

1. The problem of determining the composition of the family to confirm the need for poverty as a qualifying requirement for secondary legal assistance.

The legal conflict arose because of the unequal determination of the composition of the family in order to assign the subject the right to free secondary legal assistance as a member of a poor family. According to Part 2 of Art. 3 of the Family Code of Ukraine, a family is formed by cohabiting individuals who are connected by a common life, and have mutual rights and obligations ${ }^{17}$.

Meanwhile, in paragraph 3 of part 2 of Art. 4 of the Law of Ukraine "On state assistance to low-income families" dated June 1, 2000 it is determined that the family includes husband, wife; relatives, adopted children of these persons under the age of 18 , as well as children who study full-time in general, vocational and higher educational institutions of I-IV levels of accreditation up to the age of 23 and do not have their own families; unmarried adult children who are recognized as disabled since childhood of groups I and II or as group I disabled and living with their parents; incapacitated parents and spouses who live with them and are dependent on them due to the lack of their own income; a person living with a lonely disabled person of group I and provides care for him; a woman and a man who lives in the same family, are not married, but have children in common ${ }^{18}$.

That is, the family includes, regardless of the place of residence (stay) or registration of children attending full-time education in general educational, vocational, higher educational institutions of I-IV levels of accreditation up to 23 years and do not have their own families. The family does not include persons who are fully supported by the state.

Thus, there is no single approach to the identification of low-income and possible abuse of these persons as subjects of free secondary legal assistance.

2. Unequal interpretation of the issues of "social protection" as a sign of receiving secondary legal assistance for war veterans without taking into account their income.

\footnotetext{
${ }^{17}$ Family Code of Ukraine: Law of Ukraine of Jan. 102002 No. 2947-III. Vidomosti of the Verkhovna Rada of Ukraine (VVR), 2002, No. 21-22, p. 135.

${ }^{18}$ On state social assistance to low-income families: Law of Ukraine of June 1, 2000. Vidomosti of the Verkhovna Rada of Ukraine (VVR), 2000, No. 35, p. 290.
} 
National legislation does not provide a clear interpretation of the concept of "social protection". Article 46 of the Constitution of Ukraine it is said that citizens have the right to social protection, which provides for the right to provide, in the event of complete, partial or temporary disability, loss of a breadwinner, unemployment due to circumstances beyond their control, as well as in old age and in other cases provided for by law ${ }^{19}$. This led to a narrowing of the legal protection of war veterans.

Internally displaced persons cannot receive a certificate of family composition at their registered place of residence in the anti-terrorist operation zone as a document to confirm the status of a low-income family and receive free secondary legal assistance.

Thus, from the above, the following legislative problems can be distinguished.

Thus, from the above, the following legislative problems can be distinguished.

1) The Law of Ukraine "On Free Legal Assistant" (paragraph 2, part 1, Article 15$)^{20}$ limits the range of subjects providing free secondary legal assistance only to lawyers included into the Register of Lawyers providing this assistance, and therefore does not take into account the conventional human right to choose a lawyer. This leads to a decrease in the effectiveness of the provision of legal assistance by lawyers and the loss of legal independence as a self-governing professional institution.

2) Determining the composition of the family to confirm the need for poverty as a qualifying requirement for secondary legal assistance.

The legal conflict arose due to the unequal determination of the composition of the family in order to assign the subject for the right to free secondary legal assistance as a member of a poor family.

3) There is an ambiguous interpretation of social protection as a sign of legal assistance.

Therefore, we are convinced that the solution to these issues requires the intervention of legislators who, within the limits of their competence, will give a positive solution to these problems, taking into account the European experience on those issues.

Even today, there are many important tasks ahead of the free legal assistance system to improve its work. Among these tasks, lawyers pay special attention to solving the problem of the quality of the provision of free secondary legal assistance.

\footnotetext{
${ }^{19}$ Constitution of Ukraine: Law of Ukraine of 06.28 .1996 No. 254k/96-VR. Vidomosti of the Verkhovna Rada of Ukraine (VVR), 1996, No. 30, p. 141.

${ }^{20}$ About free legal assistance: Law of Ukraine dated 02.06.2011 No. 3460-VI. Vidomosti of the Verkhovna Rada of Ukraine (VVR), 2011, No. 51, p. 577.
} 
Ensuring the right to free legal assistance, in accordance with Art. 6 of the Convention should not be formal but real. Free legal assistance, guaranteed under Art. 6 paragraph 3, must be "concrete and effective". That is, the appointment of a public defender does not yet imply the effectiveness of such assistance, since an ex officio lawyer may die, be seriously ill, face longstanding obstacles or evade his or her duties (Artico v. Italy, paragraph 33).

Undoubtedly, coordinating efforts to ensure the quality of legal assistance is a serious step forward. The unity of views of the state legal assistance system, a professional lawyer association and non-governmental organizations can become one of the key elements of the unification of legal assistance approaches that will facilitate the networking of legal assistance providers.

The result of this collaboration was the introduction of a new quality assurance tool, called Peer Review. In fact, Peer Review is an expert rating used in scientific research, in the system of expert research and in the provision of professional assistance (including medical and legal). It is a system where independent experienced experts practice assessing the quality of work of other professionals based on specific criteria and defined levels of performance that are agreed upon in the professional community.

The concerns of the advocacy community about the implementation of the Peer Review concept in the free legal assistance system are likely to continue. However, Peer Review is the one tool that will keep a balance between resolving the problem of improving the quality of legal assistance and the guarantees of advocacy.

A series of expert consultations on improving the governance model to enhance independence and the effectiveness of the legal assistance system were held in March 2018 as part of the project "The Affordable and HighQuality Legal Assistance in Ukraine" and the project of the Council of Europe "Further Support for Criminal Justice Reform in Ukraine".

In September 2018, the expert meetings on the development of a management model concept to strengthen the independence and effectiveness of the free legal assistance system in Ukraine were held. The result was the development of a draft concept of the "FLA System Supervisory Board" and a draft resolution of the Cabinet of Ministers of Ukraine "On Amendments to the "Regulations on the Legal Assistance Coordination Center".

In addition, in July 2018, the Project organized a visit to Canada for representatives of the Ministry of Justice and the Legal Assistance Coordination Center to study Canada's experience in developing free legal assistance systems, including the creation and operation of various models of the free legal assistance management systems, as well as the establishment and deepening of working relationships and the exchange of experience between the Ukrainian FLA system and Canadian legal support organizations assistance in the provinces of Nova Scotia and British Columbia. 
The project "Affordable and High-Quality Legal Assistance in Ukraine" is ready to continue to draw on the best Canadian expertise to develop policies and procedures that will govern the future of the Supervisory Board, as well as to foster the Council's capacity as a newly created innovative institution in the area of access to justice.

The Council of Europe, as a long-standing and key partner of the FSLA system in Ukraine, has encouraged and allied independent public initiatives aimed at improving the legal assistance system. The project involved newly recruited lawyers in the legal assistance system, about 500 people from all regions of Ukraine. Pravokator Law Clubs were chosen as the venue - new venues for the interaction and exchange of experience of free legal assistance lawyers, judges, prosecutors and public experts established in the FLA system in 2017, including the support of the Council of Europe.

Lawyers have been provided with effective tools to protect the rights and representation of persons entitled to legal assistance. In particular, lawyers have learned the answers to the most common questions regarding all stages of criminal proceedings, from detention to appeal against a decision in a higher court. All aspects were considered in the light of the case law of the European Court of Human Rights - lawyers discussed which is the best way to apply legal mechanisms to protect client's rights in criminal proceedings.

The free legal assistance system disseminates best practices in the legal environment by teaching not only lawyers but also other parties to criminal proceedings. The main objective of the trainings was to discuss the best ways to provide legal assistance in accordance with the Criminal Procedure Code of Ukraine in the light of the European Convention on Human Rights. Today, the ECtHR Convention and Practice remains a kind of exotic in Ukrainian courts, while trainings allow lawyers of the free legal assistance system to apply the best international standards in their work.

A series of trainings helps to achieve several important goals. On the one hand, the project is aimed at enhancing the individual professional abilities of the lawyers of the FLA system, and therefore helps the system to become stronger and more professional. On the other hand, through cooperation with the Ukrainian Legal Assistance Foundation and other expert NGOs, it deepens the cooperation with civil society and demonstrates the importance of the FLA system as a social phenomenon. The right to an attorney is an integral part of the right to fair justice, which in turn is a cornerstone of legal reform in Ukraine.

In addition, the institutionalization of training is very important, as the standardized program and materials developed through the project can continue to be used independently and systematically in the FLA system, regardless of the projects of the Council of Europe. Similarly, a group of 
trainer lawyers, co-sponsored by the Council of Europe, operates without the need for mandatory external support.

Initial steps in the implementation of the mechanism have shown that it is indeed capable of changing the situation of assessing the quality of legal assistance and will become an important tool in the quality management system of legal assistance.

The administrative burden involved in handling legal assistance applications should be minimized. The legal framework should be improved to clearly determine the persons eligible for FLA and become simpler and more understandable to recipients of legal assistance. This can be achieved by ensuring that a separate and integrated legal assistance law comprehensively and uniformly covers all relevant aspects of legal assistance and safeguards, thus avoiding confusion in the law.

The FLA law or related by-laws should be amended to clarify whether or not legal assistance is provided throughout the proceedings; a clear procedure for the provision of legal assistance should also be developed if it is not provided throughout the proceedings.

Criminal justice entities, in particular the police, prosecutors, courts and the legal assistance system, should work together to ensure that any suspected/accused person is provided with legal assistance, from the moment of detention, to the first interrogation by police, as required by Ukrainian law and practice of the ECtHR. This may include developing (and, where appropriate, updating) by-laws that would provide early access to a lawyer for each institution concerned. Automatic detention of all suspected/accused detainees and timely notification to the RCFLA of the need to appoint a lawyer are also required. In addition, the prosecution of the only persons who are guilty and the exclusion of testimony obtained without a lawyer from the moment of detention and before the first interrogation by the police ("Salduz principle") is in the interests of the public, the police and lawyers. Therefore, training should be organized on this principle and the consequences of its violation among all relevant parties interested.

The FLA Law should specify the time limits within which legal assistance decisions may be challenged and the procedure to be followed. The various provisions on legal assistance appeals, which now contain different articles of the FLA Law, could be transposed into a single set of provisions, including review and appeal.

There is a need to improve the order in which information (oral and written) is retained in conjunction with the recording of the conversation so that the public and the lawyers are assured that their rights are properly communicated to the public. The more often this is done, the more people will be aware of their rights to information and effective protection. The 
availability of primary legal assistance in criminal matters can also be used for this purpose.

It would be useful for different institutions of the criminal justice system to collect and process statistics using similar indicators so that legal assistance data can be compared with statistics of law enforcement agencies and courts, and thus to know the percentage of criminal cases (proceedings) in which the legal assistance was necessary to be provided, and the percentage of actual recipients of legal assistance, and the reasons for any possible differences.

\section{CONCLUSIONS}

The international legal norm on the right to protection has largely been established under the influence of national legislation and the legal practice of states. However, it is obvious that national law also has a significant impact on international legal perceptions of the right to protection, especially through the prism of the ECtHR and other international human rights bodies.

In international criminal courts, the right to personal protection is regarded as an inalienable right of every accused person. As a rule, it cannot provide more effective protection than that of a qualified lawyer. It seems necessary to place greater emphasis on the qualifications of a lawyer in the international criminal justice system by providing for the experience of the applicant in the international criminal justice system, or at least the need to undergo appropriate internships or training before admitting such a person to practice as a lawyer.

Analyzing the peculiarities of the provision of such services in the European countries, it is concluded that Ukraine has already begun to move forward, taking over the European experience. The examples include primary and secondary legal assistance centers operating in all areas of Ukraine that are close to European standards. On the basis of the recommendations of the Council of Europe report on supporting the development of a free legal assistance system, it is proposed to improve the transparency of the appointment of lawyers, to strengthen the quality control mechanisms for the provision of legal assistance, to simplify the existing system of payment of lawyers based on European experience, to encourage attorneys to represent clients, and the development of electronic exchange of information between relevant authorities to ensure greater coherence in relevant authorities, their effectiveness and the improvement of service delivery to the public.

\section{SUMMARY}

The scientific publication examines the standards of access to professional legal assistance in accordance with the legislation of Ukraine and European legal doctrine. The legal framework of the Ukrainian legislation regulating the 
implementation of European standards of access to professional legal assistance is analyzed. Initial steps in the implementation of the mechanism have shown that it is indeed capable of changing the situation of assessing the quality of legal assistance and will become an important tool in the quality management system of legal assistance. The results of modern studies of the evaluative nature of public policy, which regulates the introduction of standards into Ukrainian legal realities, are characterized. The key issues relating to the provision of free legal assistance are highlighted. Initial steps in the implementation of the mechanism have shown that FLA is indeed capable of changing the situation of assessing the quality of legal assistance and will become an important tool in the quality management system of legal assistance. The author defines a system of recommendations that will help to implement European experience in the provision of professional legal assistance.

\section{REFERENCES}

1. Goncharenko S. V. Problems of providing free legal assistance. A brief overview of the latest trends // The Lawyer. 2011. № 11. P. 12-16.

2. Convention for the Protection of Human Rights and Fundamental Freedoms of 04/04/1950. Convention by Law No. 475/97-VR of 07.17.97.

3. Constitution of Ukraine: Law of Ukraine of 06.28.1996 No. 254k/96-VR. Vidomosti of the Verkhovna Rada of Ukraine (VVR), 1996, No. 30, p. 141.

4. International Covenant on Civil and Political Rights of 12.16.1966. The International Covenant was ratified by Decree of the Presidium of the Supreme Council of the Ukrainian SSR N 2148-VIII (2148-08) of 10.19.73.

5. The Bar and Advocacy: The Law of Ukraine of July 5, 2012, Vedomosti of the Verkhovna Rada (VVR), 2013, No. 27, p. 282.

6. About free legal assistance: Law of Ukraine dated 02.06.2011. No. 3460-VI. Vidomosti of the Verkhovna Rada of Ukraine (VVR), 2011, No. 51 , p. 577.

7. On refugees and persons in need of additional or temporary protection: Law of Ukraine of July 8, 2011. Vidomosti of the Verkhovna Rada of Ukraine (VVR), 2012, No. 16, p. 146.

8. On state social assistance to low-income families: Law of Ukraine of June 1, 2000. Vidomosti of the Verkhovna Rada of Ukraine (VVR), 2000, No. 35, p. 290.

9. On the Concept of the formation of a system of free legal assistance in Ukraine: Decree of the President of Ukraine of June 9, 2006 No. 509/2006.

10. On the protection of childhood: Law of Ukraine of April 26, 2001. Vidomosti of the Verkhovna Rada of Ukraine (VVR), 2001, No. 30, p. 142. 
11. On the living wage: Law of Ukraine of July 15, 1999. Vidomosti of the Verkhovna Rada of Ukraine (VVR), 1999, No. 38, p. 348.

12. About the status of war veterans, guarantees of their social protection: the Law of Ukraine of October 22, 1993. Vidomosti of the Verkhovna Rada of Ukraine (VVR), 1993, No. 45, p. 425.

13. Issues of the decentralization process of service delivery in the united territorial communities: a collection of roundtable papers and abstracts, Kyiv, April 18, 2019 / under gen. ed. of R.V. Voitovych, P.V. Vorona. Kyiv, “ArtEk", 2019. 217 p.

14. Sverba Yu. Peer Review: step by step to the quality of free legal assistance // Legal Newspaper. № 40 (694). 2019.

15. Family Code of Ukraine: Law of Ukraine of Jan. 102002 No. 2947-III. Vidomosti of the Verkhovna Rada of Ukraine (VVR), 2002, No. 21-22, p. 135.

16. Forming of the free legal assistance system in Ukraine [Electronic source]. Available at: http://legalaid.gov.ua/ua/operatyvna-info/formuvanniasystemy.

17. Legal assistance in Europe: minimum requirements under international law [Electronic source]. Available at: http://osf.to/legal-aid-standards.

\section{Information about the author: \\ Oksana Krushnitska,}

Postgraduate Student at the Department of Procedural Law, Yuriy Fedkovych Chernivtsi National University 22, Fedkovicha str., Chernivtsi, 58000, Ukraine ORCID ID: orcid.org/0000-0003-1693-9867 